\title{
An Ecosystem-Based Approach to Climate-Smart Agriculture with Some Considerations for Social Equity
}

\author{
Kofi Akamani
}

Citation: Akamani, K. An

Ecosystem-Based Approach to Climate-Smart Agriculture with Some Considerations for Social Equity. Agronomy 2021, 11, 1564. https:// doi.org/10.3390/agronomy11081564

Academic Editor: Jinyang Wang

Received: 24 June 2021

Accepted: 4 August 2021

Published: 5 August 2021

Publisher's Note: MDPI stays neutral with regard to jurisdictional claims in published maps and institutional affiliations.

Copyright: (C) 2021 by the author. Licensee MDPI, Basel, Switzerland. This article is an open access article distributed under the terms and conditions of the Creative Commons Attribution (CC BY) license (https:// creativecommons.org/licenses/by/ $4.0 /)$.
Forestry Program, School of Agricultural Sciences, Southern Illinois University, Carbondale, IL 62901, USA; k.akamani@siu.edu

\begin{abstract}
Although the transition to industrial agriculture in the 20th century resulted in increased agricultural productivity and efficiency, the attainment of global food security continues to be elusive. Current and anticipated impacts of climate change on the agricultural sector are likely to exacerbate the incidence of food insecurity. In recent years, climate-smart agriculture has gained recognition as a mechanism that has the potential to contribute to the attainment of food security and also enhance climate change mitigation and adaptation. However, several conceptual and implementation shortfalls have limited the widespread adoption of this innovative agricultural system at the landscape scale. This manuscript argues for the use of ecosystem management as an overarching framework for the conceptualization and implementation of climate-smart agriculture. The manuscript focuses on clarifying the foundational assumptions and management goals, as well as the knowledge and institutional requirements of climate-smart agriculture using the principles of ecosystem management. Potential challenges that may be faced by the application of an ecosystem management approach to climate-smart agriculture are also discussed. Furthermore, the manuscript calls for a heightened focus on social equity in the transition toward an ecosystem-based approach to climate-smart agriculture. The US farm bill is used as an illustrative case study along with other examples drawn mostly from sub-Saharan Africa.
\end{abstract}

Keywords: adaptive governance; adaptive management; agroforestry; climate change; ecosystem services; food security; integrated resource management; resilience; social-ecological systems; sustainable agriculture

"A land ethic, then, reflects the existence of an ecological conscience, and this in turn reflects a conviction of individual responsibility to the health of the land. Health is the capacity of the land for self-renewal. Conservation is our effort to understand and preserve this capacity."

([1], p. 258)

\section{Introduction}

The transition from traditional to industrial agriculture in the 20th century was largely motivated by the pursuit of short-term economic goals, including efficiency in production mechanisms and maximization of output. These goals were pursued by promoting large-scale farming, monocropping, farm mechanization, and the widespread use of agrichemicals [2-5]. Despite the short-term gains, in recent years, it has been revealed that there are shortfalls of industrial agriculture, including adverse impacts on water quality and quantity, high consumption of fossil fuels, contributions to emissions of greenhouse gases (GHGs), displacement of farm families, disruption of rural communities, and threats to biodiversity and food security [4,6-8]. According to the Food and Agriculture Organization (FAO), food security is said to exist when all people, at all times, have physical, social, and economic access to sufficient, safe, and nutritious food to meet their dietary needs and food preferences for an active, healthy life [9]. Food security is a multi-dimensional concept, comprising availability, the stability of supply, access, and utilization [10]. While 
industrial agriculture has enhanced food supply, food security is influenced more by the socio-political processes that influence access [11-13].

Since the 1980s, a paradigm shift toward sustainable forms of agriculture has been occuring in the US and other industrialized countries that seeks to overcome the shortfalls of industrial agriculture [4,14]; although, this has yet to reflect on the ground in terms of production. The emergence of sustainable agriculture is part of the broader societal transition toward sustainable development [4]. Sustainable agriculture seeks to produce adequate amounts of high-quality food while being profitable and environmentally safe [14]. According to reference [2], sustainable agricultural systems are characterized by the use of socially responsible, economically viable, and environmentally sound practices that also address the needs of future generations. Sustainable agriculture captures several attributes, including the joint production of food and other ecosystem services, minimum use of off-farm inputs, utilization of renewable sources of energy, reliance on biological processes for pest management, crop rotation, and a diversity of crops and livestock $[4,15]$. Expected benefits of sustainable agriculture include energy efficiency, soil and water conservation, reduced risk of failure, low production cost, as well as enhanced social justice and equity through participatory and social learning processes $[3,14,15]$. However, policies and research on sustainable agriculture, particularly those focused on organic agriculture, often adopt a micro-level approach focusing on farmers and the farm, thus failing to account for interactions across the multiple scales and sectors that influence agriculture $[2,16,17]$. In the US, for instance, the implementation of the Low Input Sustainable Agriculture program (LISA) aimed at reducing farmers' dependence on external farm inputs, as well as enhancing farm profitability and enironmental conservation. However, the focus was largely on the farm level [2], and it is only in recent decades that US agricultural policies have broadened to explicitly consider landscape-scale issues. Additionally, the implementation of sustainable agricultural programs could lead to unintended adverse consequences if potential synergies and trade-offs are not adequately considered $[16,18]$.

In view of the shortfalls of sustainable agriculture, the complexity of agricultural systems and the need to build adaptive capacity to withstand the impacts of drivers of change, such as climate change impacts, while providing multiple ecosystem services for the long-term benefit of humans and the environment has been gaining interest among researchers and policymakers $[6,13,17]$. Resilience-based management of agricultural systems calls for the conceptualization of agricultural systems as dynamic and complex social-ecological systems subject to influences and surprises across multiple scales $[19,20]$. Managing for enhanced resilience in agricultural systems also requires integrated decision making to identify synergies and trade-offs, the use of multi-disciplinary approaches, and multi-level governance mechanisms that promote vertical and horizontal linkages among diverse stakeholders [21,22]. These insights appear to have given rise to the emergence of climate-smart agriculture, an emerging concept that aims at enhancing productivity in agricultural systems, while also promoting climate change mitigation and adaptation efforts [23]. While climate-smart agriculture is a promising mechanism for enhancing sustainability in agricultural systems, the implementation of this innovation has been hampered by ambiguities regarding its conceptual scope and institutional mechanisms [24,25]. These ambiguities have sometimes blurred the distinction between climate-smart agriculture and the conventional industrial, agricultural model [26]. If climate-smart agriculture is to achieve its true potential as a means for facilitating "a transition to agriculture and food systems that are more productive, more sustainable and more climate-friendly" ([27], p. 2), then further refinement of the conceptual basis, methodological tools, and implementation mechanisms is required.

This manuscript proposes the concept of ecosystem management as a promising framework for the implementation of climate-smart agriculture (Figure 1). Although significant overlap exists between the literature on ecosystem management and climatesmart agriculture, the wealth of knowledge accumulated from decades of research and policy implementation on ecosystem management could contribute to addressing some of 
the current challenges in the climate-smart agriculture literature. The next section of the manuscript discusses the intersections between climate change and agricultural systems and the challenges this creates for the attainment of food security. Next, climate-smart agriculture and its key shortfalls are discussed. Following this, the next two sections discuss the ecosystem management concept and reflect on how its key attributes could inform policies to promote climate-smart agricultural systems. The subsequent section highlights the need for an enhanced focus on social equity in the transition toward climate-smart agriculture. Following this, the US farm bill is presented as a case study to illustrate the strategies and challenges entailed in promoting an ecosystem-based approach to climatesmart agriculture. The last section of the chapter offers concluding remarks on promoting an ecosystem-based approach to climate-smart agriculture.
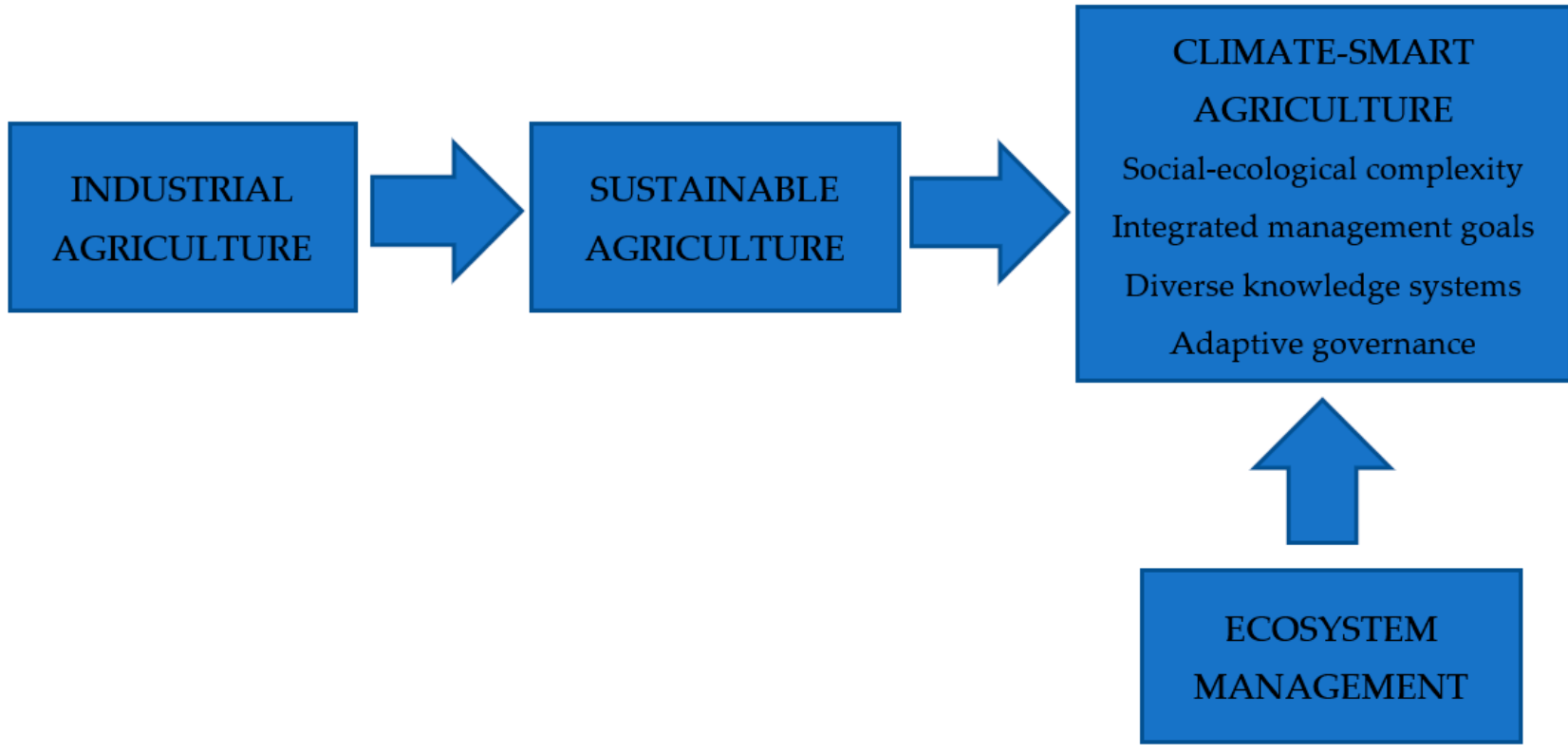

Figure 1. Ecosystem management and climate-smart agriculture.

\section{Climate Change Impacts on Agricultural Systems}

The impacts of climate change on the agricultural sector have been receiving significant research and policy attention in recent decades [11,28,29]. The Intergovernmental Panel on Climate Change (IPCC) has recently released a special report estimating that human activities have contributed about $1.0^{\circ} \mathrm{C}$ of global warming above pre-industrial levels [30]. The report further projected that if current trends continue, global warming could reach $1.5{ }^{\circ} \mathrm{C}$ between 2030 and 2052. Human and natural systems are likely to experience increased climate-related risks from the increase in mean temperature, sea-level rise, heavy precipitation, and the incidence of drought that will result from these trends in global warming [30]. Agriculture is "a direct victim of climate impacts" ([31], p. 1), and the situation is especially so in developing countries where high levels of dependence on agriculture as a source of livelihood, predominance of rain-fed agricultural systems, and low adaptive capacities create high levels of vulnerability [11,32-34].

A broad goal of public policy in the agricultural sector at the national and global levels in recent decades has been the attainment of food security [35]. While food supply per capita has increased by more than 30\% since 1961, the goal of food security remains elusive, with an estimated 821 million people currently undernourished [36]. Through increasing temperatures, changing precipitation patterns, and an increase in the frequency and intensity of floods and drought, climate change is already adversely impacting agricultural productivity and food security, and the situation is expected to worsen with projected future climate change $[23,36]$. The impacts of climate change on the agricultural sector are likely to be compounded by non-climate drivers of change, including the changing 
consumption patterns resulting from increased urbanization, population growth, and rising income levels $[6,8,23,36]$.

While the impacts of climate change on the agricultural sector have received a lot of attention, it is also worth noting that agriculture is both a cause and a potential solution to climate change. The agricultural sector is one of the major contributors to global warming $[4,23]$. It has been estimated that crop production and livestock farming activities contribute $10-12 \%$ to GHG emissions, while another $8-10 \%$ of emissions come from changes in land cover, as well as changing land use patterns [36]. Given the challenge of increasing food production by 50 percent to feed an expected population of almost 10 billion people by 2050 [31], GHG emissions, as well as other environmental consequences from the agricultural sector, are likely to increase in the future due to the expansion of livestock and crop production systems, land cover change, and the increased use of fertilizer, among other factors [24,33]. Because of these current and future challenges, more innovative mechanisms are necessary as means for enhancing the sustainability of agricultural systems $[6,11]$. Such a shift should also contribute to the realization of the potential of agriculture as a solution to climate change.

\section{Climate-Smart Agriculture}

Climate-smart agriculture has recently emerged as a response to the need for agricultural systems that can enhance food security while promoting climate change mitigation and adaptation efforts $[24,29,31]$. The FAO proposed the climate-smart agriculture concept at the Global Conference on Agriculture, Food Security, and Climate Change at The Hague in 2010 [24,25]. Since then, it has been applied by numerous international organizations and national governments in dozens of countries around the world [27,29]. Climate-smart agriculture primarily aims at sustainably managing agricultural systems to attain food security while also harnessing the potential of the agricultural sector for climate change mitigation, as well as adaptation to climate change impacts [23]. According to the FAO, climate-smart agriculture has three interlinked objectives: "sustainably increasing agricultural productivity and incomes; adapting and building resilience to climate change; reducing and/or removing greenhouse gas emissions, where possible" ([27], p. iv). Climatesmart agriculture is closely linked with sustainable agriculture, sustainable intensification, agroecology, and other related concepts $[25,29,33]$. However, a defining feature of climatesmart agriculture is its emphasis on analyzing the synergies and trade-offs among food security, adaptation to climate change impacts, and climate change mitigation [23]. Thus, climate-smart agriculture promises to achieve simultaneous gains in adaptation, mitigation, and productivity by maximizing synergies and minimizing or avoiding trade-offs among the three objectives [24,27].

Although climate-smart agriculture holds promise as a concept for addressing some of the pressing challenges in the agricultural sector, it has also received several criticisms. Conceptually, climate-smart agriculture has been critiqued for lacking a precise definition, making it difficult to decide what kinds of agricultural practices are included or excluded from the concept. This lack of conceptual clarity makes climate-smart agriculture susceptible to being co-opted by industrial, agricultural interests for purposes that depart from the intended goals of the concept [26]. Closely related to the point above, the literature on climate-smart agriculture has also been critiqued for the lack of clarity on the interactions among the three objectives, thus often resulting in the implementation of projects that focus on one objective to the neglect of the others [24,25]. Another major criticism is that the implementation of climate-smart agricultural initiatives has often focused on the farm, with little attention being devoted to developing mechanisms for implementing the concept at the landscape scale [29]. Given the site-specific focus of current climate-smart agricultural initiatives, program implementation processes often fail to include stakeholders from relevant sectors, such as food, energy, and water; management goals rarely consider the impacts of agriculture on other ecosystem services [24]. Finally, climate-smart agriculture has also been critiqued for adopting a business-as-usual approach that embraces most of 
the attributes of industrial agriculture, such as the high dependence on agrichemicals and other external farm inputs, as well as its reliance on the global market system $[25,26]$. The next section of the chapter draws from the literature on ecosystem management to address some of these limitations.

\section{Resilience and Ecosystem-Based Management}

Over the last several decades, the dominant paradigm for resource management has been evolving from an emphasis on maximum sustained yield toward ecosystem management [37-39]. Based on the assumption that ecosystems fluctuate predictably around a single equilibrium, resource managers in the era of sustained yield resource management sought to control the natural variation in ecosystems to ensure efficiency and predictability in the supply of a few economically valuable commodities [40-43]. The reduction in diversity and loss of resilience resulting from such management practices have led to the collapse of ecosystems $[40,44]$.

Since the 1970s, new perspectives have emerged about ecosystem dynamics and the relationship between humans and nature. Contrary to older assumptions about the stability of ecosystems near a single equilibrium, an alternative perspective that conceptualizes social and ecological systems as dynamic and inter-dependent social-ecological systems that are characterized by multiple stable equilibria is increasingly being embraced $[42,45]$. Social-ecological systems demonstrate the features of complex adaptive systems, including nonlinearity, path dependence, emergence, heterogeneity, surprise, thresholds, and scale sensitivity, and this presents challenges for the attainment of conventional management goals $[46,47]$. The concept of resilience has been proposed as an appropriate goal for managing social-ecological systems [48]. Based on the work of [49], resilience in ecosystems refers to the magnitude of disturbance a system can absorb before it changes its structure and functions [40]. The broader concept of social-ecological resilience has three interrelated meanings: the amount of shock the system can absorb while remaining in a given state; the capacity of the system for self-organization; the extent to which the system can build the capacity for learning and adaptation [41].

Given the failures associated with the sustained yield resource management paradigm, the emerging ecological understanding of the complexity of social-ecological systems, as well as changing societal values, ecosystem management has been receiving attention as a more useful paradigm for resource management [43,50,51]. Ecosystem management refers to "an integrated approach to management that considers the entire ecosystem, including humans, and the full spectrum of ways people use, benefit from, and value nature" ([39], p. 292). The overall goal of ecosystem management is to sustain the capacity of ecosystems to provide goods and services on which humans depend even when the ecosystem is facing change and uncertainty [37]. The key principles of the ecosystem management approach include recognition of the dynamic interdependence between humans and nature; use of diverse sources of knowledge; pursuit of integrated management goals; managing at the landscape scale; promotion of adaptive management processes; utilization of collaborative institutional mechanisms [39,50,52-54].

\section{Ecosystem Management and Climate-Smart Agriculture}

The ecosystem management approach has important implications for the pursuit of climate-smart agricultural policies. However, this potential opportunity has not been systematically explored in the existing literature. In this section, the key principles of ecosystem management are elaborated upon and their implications for climate-smart agriculture are also discussed (Table A1). Potential challenges that are likely to be encountered in the application of an ecosystem-based management approach to climate-smart agriculture are also highlighted (Table A2). 


\subsection{Embracing the Complexity of Social-Ecological Systems}

Ecosystem management is explicitly based on a complex systems perspective that embraces the dynamic interactions between human societies and ecological systems over time [54-56]. Social-ecological systems are made up of interdependent parts across multiple levels, and the cross-scale interactions among various components of the system leave room for both gradual and abrupt changes [57-59]. For the enhancement of the sustainability of such complex systems, it requires nurturing the capacity for both adaptability and transformability $[43,60]$. Whereas adaptability refers to the ability of a system to deal with drivers of change while maintaining its structures and functions within a given regime, transformability entails the capacity to create a new system when prevailing conditions become undesirable [60-62]. Adaptive management is a process for building social-ecological resilience and reducing vulnerability in ecosystem management processes [63]. The adaptive management process is based on the assumption that knowledge about social-ecological systems will never be complete, and yet, resource management must proceed [64]. Stemming from this assumption, the aim of adaptive management is to promote learning as an outcome of the resource management process [65].

In the case of the agricultural sector in particular, the emergence of industrial agriculture was underpinned by a static and equilibrium-centered view of ecosystems [20], as well as a belief in human dominion over nature [3]. However, recent knowledge on social-ecological systems has revealed that the pursuit of narrow economic benefits in industrial agriculture without adequate consideration of complexity and uncertainties increases the risk of social-ecological traps and the likelihood of catastrophic regime shifts in agricultural systems $[19,21,66,67]$. Despite these lessons, the literature on climate-smart agriculture does not appear to embrace the social-ecological systems perspective that underpins ecosystem management explicitly. In the absence of an explicit emphasis on complexity thinking, there is the risk that some climate-smart agricultural policies may be based on assumptions of predictability and simple cause-effect relationships, thus giving rise to undesirable outcomes [68,69]. Reference [24] has highlighted the need for climate-smart agricultural initiatives to move beyond current incremental approaches toward prioritizing adaptive management, as well as building the capacity for transformational change in the agricultural sector. To enhance success in the application of these principles in the agricultural sector, it is essential to recognize barriers that have been identified in the implementation of adaptive management in other contexts, including inadequate stakeholder engagement, lack of political will on the part of resource managers and decision makers, lack of prioritization of active experimentation, failure to apply new knowledge in decision making, lack of appropriate monitoring protocols, as well as limited funding and personnel $[51,63,64,70,71]$. The vulnerability of agricultural landscapes could also present challenges for the implementation of active adaptive management that entails using the management process as an experiment to test policy hypotheses. In West Africa, for instance, most farming systems are located in vulnerable regions that are characterized by aridity and soil infertity problems [34], thus increasing their sensitivity to climate change. Investments in appropriate infrastructure and the use of the precautionary principle will, therefore, be needed in the implementation of adaptive management as part of climate-smart agriculture in such fragile ecosystems.

\subsection{Promoting Integrated Management Goals}

The integration of social, economic, and ecological interests across multiple scales is another key feature of the ecosystem management approach [22,38,50,72]. According to ([73], p. 533), the aim of the ecosystem management approach is "to maintain ecosystem functions ... in such a way as to meet the social and economic needs of current and future generations." This holistic management approach is pursued at the broader landscape scale using appropriate ecological boundaries that often span multiple land ownership types and jurisdictions [52,74,75]. Decision making in ecosystem management calls for mechanisms for coordinating efforts among stakeholders across administrative boundaries 
to identify the synergies and trade-offs that exist among the multiple ecosystem services that are produced in a given landscape $[43,63,73]$.

Although climate-smart agriculture seeks to enhance farm productivity, as well as climate change mitigation and adaptation, existing studies indicate that current climate-smart initiatives largely focus on the farm level [29], and most projects fail to consider all three objectives simultaneously [24,25]. As such, there is the potential for the implementation of climate-smart agricultural initiatives to result in unintended adverse consequences. For instance, a recent analysis of trade-offs among various ecosystem services revealed that the implementation of agricultural adaptation policies resulted in a decline in freshwater quality [76]. To avoid such unintended consequences, an ecosystem-based approach to climate-smart agriculture appears promising as a mechanism for enhancing synergies and reducing trade-offs among food security, climate change mitigation, and adaption, as well as other ecosystem services. Potential challenges that are likely to be encountered in such an integrated management approach include the lack of methodological and analytical tools for assessing the full range of ecosystem services and analyzing the relationships among them $[43,50]$ and differences in the philosophies, values, and interests of the diverse stakeholders that make ecosystem management a wicked problem [63]. These challenges can be overcome where political will and enabling policies exist for mainstreaming climate change considerations into existing policies on agriculture and related sectors. In Ghana, for instance, the National Climate-Smart Agriculture and Food Security Action Plan (2016-2020) was adopted through the coordinated efforts of the Ministry of Food and Agriculture and the Ghana Climate Change, Agriculture, and Food Security Science-Policy Platform [34].

\subsection{Developing Diverse Knowledge Systems}

Ecosystem management adopts a broad approach to meeting the knowledge requirements for sustainably managing the complexity of social-ecological systems by moving beyond the dominant focus on positivist science toward recognizing diverse systems of knowledge $[43,50,77,78]$. In this regard, knowledge generation through various forms of collaboration among disciplines across the social and ecological sciences is strongly encouraged in the science that informs ecosystem management $[38,50,79]$. Moreover, integrating local and traditional ecological knowledge with modern science is also seen as essential in providing a more holistic understanding of ecosystem dynamics $[45,78,80]$. In recent years, social learning and knowledge co-production are also being promoted by using participatory processes in ecosystem management $[78,81]$. Where conditions are favorable, the social interaction that occurs within participatory processes could result in a change in understanding at the collective level and potentially facilitate collective responses to the impacts of drivers of change [71,82].

The need for integrating diverse systems of knowledge in understanding the complexity of agriculture and food systems has been gaining recognition in recent years $[13,20]$. Modern agriculture has traditionally been dominated by the use of positivist science [83]. In the classical diffusion model, agricultural innovations are assumed to be developed by public sector institutions in a centralized manner and then transmitted to farmers who are treated as passive recipients of the technology [84]. The failures associated with this top-down technology transfer model have led to a shift toward participatory learning approaches that actively engage farmers and integrate traditional knowledge in technology development [20]. Consistent with these trends, the utilization of a diverse array of scientific and non-scientific sources of knowledge in climate-smart agricultural initiatives from an ecosystem management perspective could provide several benefits, including enhancing the adoption of innovations, such as agroforestry, that could contribute to food security, in addition to climate change mitigation and adaptation [54]. A recent review paper on West Africa revealed the existence of valuable indigenous knowledge and farming techniques, such as planting pits and conservation agriculture that could constitute the basis for promoting climate-smart agriculture. Planting pits that are widely used in the 
Sahel region, including Mali, Niger, and Burkina Faso, have been found to contribute to the conservation of soil and water resources while enhancing the yields of crops, such as sorghum, millet, and maize [34]. However, it must be noted that knowledge integration in an ecosystem-based approach to climate-smart agriculture is likely to encounter several hurdles, including differences in worldviews, analytical frameworks, and methods among disciplines, as well as unequal power relationships and lack of trust among participants $[78,85,86]$.

\subsection{Nurturing Adaptive Governance Mechanisms}

The successful realization of the goal of achieving desired social, economic, and ecological outcomes across multiple scales in ecosystem management processes requires effective institutional mechanisms that can connect actors across different levels and sectors [87]. In this regard, multi-level institutions, such as co-management, adaptive co-management, and adaptive governance, have received attention as useful institutional mechanisms for ecosystem management [81,88-90]. The concept of co-management, which refers to the sharing of rights, power, and resource management responsibilities between local communities and government representatives, emerged as a response to the shortfalls associated with the reliance on governments, communities, and markets as panaceas in the resource management process [91,92]. While co-management has the potential to contribute to the attainment of good governance through enhanced opportunities for participation, accountability, equity, efficiency, and effectiveness [93,94], it has also been critiqued for its lack of explicit emphasis on the complexity and uncertainties that are entailed in ecosystem management [95]. Adaptive co-management integrates theoretical insights from co-management and adaptive management, thus resulting in an institutional arrangement that combines the vertical and horizontal linkages of co-management with the learning attribute of adaptive management [89,91]. However, adaptive co-management appears more useful in situations that involve building the capacity to respond to the impacts of drivers of change while remaining within the existing regime [62].

Adaptive governance is increasingly favored as an institutional mechanism for building the capacity for adaptation and transformation in social-ecological systems, as well as promoting an integrated management approach in ecosystem management [47,81,96-98]. According to ([99], p. 9), "AG [adaptive governance] is born from the social will to manage SESs [social-ecological systems] holistically for either increased resistance to change or the ability to transform a system to a more desirable state." Although adaptive governance is closely related to adaptive management, the scope of adaptive governance covers the wider social and governance context within which the ecosystem management approach is implemented [81,100]. A defining feature of adaptive governance is the use of analytic deliberation as a decision-making process. Reference ([101], p. 1910) refers to analytic deliberation as "Well-structured dialogue involving scientists, resource users, and interested publics, and informed by analysis of key information about environmental and human-environment systems." Analytic deliberation represents an alternative to the use of technical analysis as a means of decision making in conventional resource management [102]. Analytic deliberation provides a mechanism for reconciling conflicting stakeholder values and interests, as well as dealing with uncertainties in knowledge, thus making adaptive governance an effective mechanism for managing wicked problems in ecosystem management processes [59,103].

With regard to its institutional structure, adaptive governance relies on various institutions that are nested across multiple scales [101]. The multiple centers of decision-making authority within the nested institutional structure of adaptive governance allows for making decisions at the lowest level possible, thereby enhancing the fit between resource management problems and policy interventions [87]. The diversity of institutions within adaptive governance systems, such as states, markets, and communities, also minimizes the likelihood of failure that is associated with the reliance on only one type of institutional mechanism [104]. In all, this polycentric institutional structure of adaptive governance 
contributes to building resilience through the provision of opportunities for learning and experimentation, mobilization and sharing of information and resources, and creation of opportunities for social interaction that could lead to the emergence of social capital for collective action $[105,106]$.

As part of the turn toward participatory learning approaches and the recognition of local knowledge in the development and transfer of agricultural technologies, alternative community-based institutional mechanisms for agricultural research and development have emerged to facilitate farmer participation $[20,107,108]$. Moreover, growing recognition of the complexity of agricultural social-ecological systems has led to calls for the use of adaptive, multi-level institutional mechanisms in managing agricultural landscapes for enhanced resilience [109]. In furthering these trends, embracing adaptive governance as part of an ecosystem-based approach to climate-smart agriculture could provide an effective mechanism for connecting diverse actors representing states, markets, and communities across multiple levels. Reference [107] discusses the potential roles of a diverse range of institutional mechanisms in scaling up climate-smart agriculture, including market-driven approaches, cooperatives, social movements, and community-based institutions. The author highlights the importance of farmer cooperatives and community-based institutions in the mobilization of resources for the adoption of climate-smart agricultural innovations in sub-Saharan African countries, such as Rwanda, Ethiopia, and Kenya. The use of adaptive governance institutions, therefore, has the potential to coordinate the different types of institutional mechanisms to facilitate the mobilization of information and resources, the provision of economic and non-economic incentives, and the creation of opportunities for participation, all of which are essential requirements for the adoption of agroforestry [54] and other climate-smart agricultural practices $[110,111]$. However, potential barriers in the implementation of this innovative institutional mechanism may include difficulty in overcoming the path-dependent effects of the older regime (industrial agriculture), fragmentation of responsibilities and authority among diverse organizations, organizational and financial challenges in the design of institutions for landscape-scale cooperation, and potential for undesirable social and ecological outcomes [51,71,87,106,112].

\section{Enhancing Social Equity in an Ecosystem-Based Approach to Climate-Smart Agriculture}

The attainment of social equity is one of the central challenges in the agricultural sector, as well as the broader field of resilience and sustainable development [113-115]. Social justice and equity concerns are particularly pertinent in situations involving transformational change [116], such as the transition toward climate-smart agriculture [107]. This section does not attempt to provide a comprehensive review of the literature on social justice and equity across social science disciplines, such as economics and philosophy. Rather, it briefly discusses these concepts with a focus on the resource conservation literature. In the field of resource conservation and development, the equity concept has multiple dimensions: distribution, procedure, and recognition $[113,117]$. Distributional equity is generally concerned with fairness in the allocation of the costs and benefits of conservation and development efforts among various segments of society [117]. Procedural equity relates to fairness in the mechanisms for decision making, including the application of existing rules and policies, as well as opportunities for stakeholder participation [113,117]. Equitable recognition is concerned with the respect and appreciation of the diversity of knowledge claims, worldviews, values, beliefs, norms, and other attributes that characterize the broad range of stakeholders involved in conservation and development efforts [117].

Similar to other systems approaches [114], the holistic perspective of the ecosystem management approach that has been proposed in this manuscript as a framework for the implementation of climate-smart agriculture raises social equity concerns, such as the potential for sacrificing individual components in the interest of the whole that constitutes the primary focus $[114,118]$. Reference [114] also highlights the need to pay attention to disparities among social groups in the period before, during, and after the implementation of policy interventions aimed at building resilience, and this is particularly relevant for the 
discussion on the transition toward climate-smart agriculture. Prior to the implementation of policies aimed at enhancing the transition toward climate-smart agriculture, differences in access to the resources and institutional mechanisms that shape resilience implies that different social groups may have varying levels of ability to successfully respond to the policy implementation process $[107,110]$. Insights from the literature on community resilience suggests that these contextual differences in adaptive capacity could further manifest in differences in the way various social groups respond to and are impacted by the policy implementation process [92,95]. Thus, there is the likelihood that the neglect of these contextual issues in the implementation of conservation policies, such as those promoting climate-smart agriculture, could lead to policy failures [107].

Enhancing social equity or fairness in the process and outcomes of transitions in social-ecological systems requires the use of effective institutional mechanisms that are also inclusive and efficient [119]. In the context of climate-smart agriculture, reference [107] highlights the importance of institutional attributes, such as accountability, capacity building, flexibility, and recognition of local institutions and local knowledge. The analytic deliberation process of adaptive governance discussed in this manuscript holds promise for meeting these institutional requirements through the opportunities it provides for stakeholder representation and meaningful participation in decision-making processes [120]. Moreover, institutional attributes, such as subsidiarity, that allow for the redistribution of power among actors are also essential for enhancing equity and social justice [113]. It appears the diverse and nested institutional structure of adaptive governance could help overcome the power imbalance that constitutes a source of social inequity at global and local levels, as it offers opportunities for the utilization of the full range of formal and informal institutional mechanisms used by various social groups, as well as the allocation of decision-making authority at appropriate levels, starting from the local level. Anticipating and devising mechanisms to overcome potential challenges in the use of adaptive governance mechanisms could help enhance social equity in the transition toward an ecosystem-based approach to climate-smart agriculture.

\section{Case Study: The US Farm Bill}

Since the 1930s, a major policy instrument that has shaped the agricultural sector in the US is the farm bill. Over the years, the focus of the farm bills has shifted toward a more collaborative approach aimed at achieving a broad range of socio-economic and environmental goals at the landscape scale. However, more remains to be done for this legislation to serve as a framework for promoting an ecosystem-based approach to climate smart agriculture while also addressing social equity concerns. This section provides an overview of some of the key changes in the focus of the farm bill in recent decades, as well as some of the shortfalls associated with it.

The first farm bill, the Agricultural Adjustment Act, was adopted in 1933 as part of federal emergency relief packages in response to the Great Depression and the Dust Bowl $[18,121]$. Although a major focus of the legislation was to inject cash into rural economies by establishing a price support mechanism for farm produce, this support was tied to farmers' voluntary participation in programs aimed at reducing production [121]. Given the widespread perception of environmental crises from the experience of the Dust Bowl, subsequent policies in the 1930s sought to promote payment for soil conservation as a mechanism for transferring cash to farmers while managing surplus supply [18,121,122]. Although these early agricultural policies were successful in providing much needed financial assistance to farmers, they were less successful in dealing with the problem of excess agricultural production due to the emergence of new farming technologies. Besides, these policies also tended to encourage specialization rather than diversified farming systems [18]. Reference [123] has also contended that the conservation component of these policies was only intended to serve as a means of providing support for large-scale industrial agriculture rather than being treated as an end goal. This production-oriented 
focus continued over the decades with various modifications until more radical reforms occurred in the 1980s.

The 1985 farm bill was the first to explicitly focus on natural resource conservation as an end goal in US agricultural policy rather than only as a means of managing supply [121]. This legislation has also been credited for being the first to introduce the concept of sustainable agriculture into agricultural policy in the US [4,67]. Under this legislation, several new programs were introduced for various purposes, including soil conservation, as well as the protection of wetlands, grasslands, and wildlife habitat [18]. Among them is the Conservation Reserve Program (CRP), a land retirement program that provides financial assistance to farmers who voluntarily agree to remove environmentally sensitive land, such as erosion-prone land, from production, typically for a period of 10 to 15 years [124]. The conservation focus of the 1985 farm bill continued through the 1990s with the introduction of other initiatives, such as the Wetland Reserve Program and an emphasis on natural ecosystems and larger landscapes beyond the individual farm in the 1990 Food, Agriculture, Conservation and Trade Act [121]. Several conservation programs were also introduced in the 1996 farm bill, among which is the Environmental Quality Incentives Program (EQIP). The EQIP is a working lands program, a category of programs that allows enrolled lands to remain in production while producers are paid to adopt conservation practices [124]. The 2002 farm bill further broadened the environmental agenda of agricultural policy by explicitly introducing energy conservation as a primary focus, and this energy focus was refined in the 2008 farm bill to move away from grain-based biofuel toward secondgeneration biofuels [18].

More recently, the turn toward ecosystem management on agricultural landscapes has been further boosted by the 2014 and 2018 farm bills. Among the key provisions of the 2014 farm bill are: reauthorization of larger land retirement and working lands conservation programs, such as CRP and EQIP; consolidation of other conservation programs into these larger programs to reduce conflict and enhance efficiency; authorization of a new Agricultural Conservation Easement Program (ACEP) for protecting natural resources and agricultural landscapes; authorization of a new Regional Conservation Partnership Program (RCPP) for addressing landscape-scale environmental problems [124,125]. The RCPP component of this legislation provides opportunities for the mobilization of funding and other resources among state and non-state actors across multiple levels [124] and suggests a turn toward decentralized governance of agricultural landscapes [126]. Similarly, the 2018 farm bill, which has been described by reference [127] as "generally incremental or modest" (p. 836), reauthorizes large-scale conservation programs, such as CRP and EQIP, promotes the purchasing of conservation easements for resource protection through ACEP, and emphasizes collaborative approaches to landscape-scale conservation through increased funding for RCPP [128].

In all, it appears that the goals of the farm bill policies have been gradually shifting from an earlier focus on the use of conservation as a means of providing financial support to farmers and managing excess supply toward embracing ecosystem management principles, such as the promotion of multi-level collaboration, landscape-scale conservation, and the pursuit of multiple goals. These positive trends notwithstanding, several flaws have been identified in the implementation of farm bill policies, such as the continued emphasis on efficiency and stability to the neglect of complexity and resilience in agricultural systems [67], inadequate consideration of trade-offs among the various conservation and production goals [18], marginalization of indigenous farming systems [129,130], decline in funding for research on alternative agricultural systems [14,123], lack of incentives for sustainable agricultural practices $[4,14]$, neglect of systemic racism and other structural constraints that limit access of farmers and ranchers of color to conservation programs [122,129,131], and lack of prioritization of climate-friendly agricultural practices [123]. These issues highlight the challenges associated with the transition toward ecosystem-based management.

The shortfalls of the farm bill regarding social equity and justice require further elaboration here. A study analyzing agricultural land ownership patterns in the US in the 
late 1990s found that minority groups, comprising African Americans, Native Americans, Asians, and Hispanics, constituted less than 4 percent of all landowners and held only 2 percent of private agricultural land [132]. The loss of agricultural land among African American farmers and the resultant decline in their participation in the US agricultural sector has received significant research attention in recent decades. For instance, between 1910 and 1997, land ownership by African American farmers declined from a peak of 16-19 million acres to just 1.5 million acres [132,133]. Similarly, the number of African American farmers declined from 926,000 in 1920, representing 14 percent of all farmers to about 20,000 by 1997, constituting just 1 percent of the population of farmers in the country $[133,134]$. Key among the reasons that have been cited for these trends is the persistence of discriminatory implementation mechanisms in the agricultural sector that limit access of African American farmers to federal government agricultural programs, such as the farm bill conservation programs [122,131,134]. In 1999, a settlement agreement was reached in a class action discrimination law suit that had been filed by Black farmers against the US Department of Agriculture for its discrimination in the allocation of farm loans. The agreement entailed a settlement of USD 50,000 to each claimant, as well as loan forgiveness. Additionally, in 2010, another settlement of USD 1.25 billion was announced due to the large number of Black farmers whose claims were not addressed under the first settlement [135]. Nonetheless, recent studies suggest systemic discrimination still persists in the administration of farm bill programs. Using a participatory action research approach that involved researchers and Black farmers in the state of Oklahoma, reference [131] documents how the lack of access to resources, lack of access to reliable information about farm bill programs, such as EQIP, and lower rates of approval of applications for program funds by Black farmers than their white counterparts all work to constrain the capacity of Black farmers to eradicate the eastern red cedar, an invasive species that is having a disproportionately adverse impact on Black farmers in that state.

Besides these farm bill initiatives, a few initiatives have been adopted in recent years to explicitly address climate-smart agriculture in the US at the federal level. In 2015, the Secretary of Agriculture announced a new initiative, Building Blocks for Climate Smart Agriculture Forestry. Similar to farm bill policies, this initiative sought to rely on voluntary and incentive-based mechanisms to promote the adoption of climate-smart agricultural practices by farmers, ranchers, and forestland owners. The initiative aims to achieve various economic and environmental benefits on working lands through partnerships among producers, government agencies, tribes, states, and other actors. This initiative was designed to utilize existing farm bill conservation programs, such as EQIP and CRP, as mechanisms for meeting the commitment of the US under the Paris Agreement [136]. More recently, in January 2021, President Joe Biden signed a new Executive Order aimed at addressing the climate crises. A 90-day progress report on this Executive Order based on listening sessions with 260 participants, as well as 2700 comments in response to a Federal Register Notice, offered several recommendations for a climate-smart agriculture and forestry strategy. They include: developing of appropriate protocols for quantifying benefits; promoting inclusivity by expanding opportunities and removing barriers to participation; leveraging existing farm bill conservation programs to support climate smart agriculture and forestry; expanding education, outreach, and technical assistance programs; promoting landscape-scale conservation; enhancing the resilience of forests to wildfire and climate change impacts [137]. However, it remains to be seen as to how many of these recommendations will be adopted and implemented as policies to promote climate smart agriculture in an equitable manner.

\section{Conclusions}

Over the last decade or so, the concept of climate-smart agriculture has received attention from researchers and policymakers as a response to the need for agricultural systems that could enhance the attainment of food security while contributing to efforts focused on climate change mitigation and adaptation. However, various conceptual 
and implementation challenges have limited the widespread adoption of this innovative agricultural system. It appears that climate-smart agriculture may have borrowed some of the limitations of the industrial, agricultural paradigm from which it evolved. In this manuscript, the concept of ecosystem management was proposed as a promising approach for the operationalization and implementation of climate-smart agriculture at the landscape scale. The application of the principles of ecosystem management to climate-smart agriculture could help clarify the foundational assumptions and goals of climate-smart agriculture, as well as its knowledge and institutional requirements, thus setting it apart from the attributes of industrial agriculture. The principles discussed here align with and complement ongoing discussion on sustainable and resilient agricultural systems from the perspective of ecoagriculture [138], landscape approaches $[139,140]$, and agroecology $[141,142]$. However, given the applicability of the ecosystem management concept across diverse resource management arenas, it offers opportunities for a truly multi-sectoral approach to reconciling competing demands for enhanced food security as well as climate change mitigation and adaptation. Moving toward an ecosystem-based approach to climate-smart agriculture will, however, require the ability to break away from the path-dependent effects of the dominant industrial, agricultural paradigm. Thus, the mechanisms by which the process of social-ecological transformation toward an ecosystembased approach to climate-smart agriculture can be navigated require research and policy attention. Of particular importance is the need to pay attention to issues of social equity and justice in the process and outcomes of the transition process. Investments in adaptive governance may help overcome the path-dependent effects of industrial agriculture and contribute to a successful and equitable transition toward an ecosystem-based approach to climate-smart agriculture.

Funding: This research was funded by USDA National Institute of Food and Agriculture, McIntire Stennis project, grant number 1020037.

Institutional Review Board Statement: Not applicable.

Informed Consent Statement: Not applicable.

Data Availability Statement: Not applicable.

Acknowledgments: I am grateful to the two anonymous reviewers for their insightful comments that significantly enhanced the depth of the manuscript.

Conflicts of Interest: The author declares no conflict of interest. The funders had no role in the design of the study; in the collection, analyses, or interpretation of data; in the writing of the manuscript, or in the decision to publish the results.

\section{Appendix A}

Table A1. Ecosystem-based strategies for climate-smart agriculture.

\section{Assumptions: Embrace the complexity of social-ecological systems}

- Recognize agricultural systems as complex social-ecological systems;

- $\quad$ Prioritize the need to build capacities for adaptation and transformation;

- Manage uncertainties and build resilience using adaptive management.

Management goals: Promote integrated management goals

- $\quad$ Recognize the diversity of social, economic, and ecological values produced on agricultural landscapes;

- Analyze the synergies and trade-offs between climate change policies and food, energy, and water security;

- Manage at the landscape scale by coordinating management efforts across land ownership types and administrative boundaries;

- $\quad$ Promote cooperation between agriculture and related selectors, such as energy, water, and forestry. 
Table A1. Cont.

\section{Knowledge requirements: Develop diverse knowledge systems}

- $\quad$ Promote knowledge integration between the social and ecological sciences through multi-disciplinary, interdisciplinary, and transdisciplinary research;

- $\quad$ Recognize the importance of traditional knowledge and promote the integration of traditional knowledge with modern scientific knowledge;

- $\quad$ Facilitate participatory processes for social learning and knowledge co-production.

\section{Institutional requirements: Nurture adaptive governance mechanisms}

- Use analytic deliberation processes to manage conflicting values and knowledge uncertainties among stakeholders;

- $\quad$ Engage different types of institutions, representing states, markets, and communities;

- Develop multi-level institutions that connect actors at multiple levels and provide opportunities for decision making at the lowest appropriate level.

Table A2. Challenges for ecosystem-based climate-smart agriculture.

Challenges in pursuing adaptive and integrated management goals

- Differences in worldviews, e.g., anthropocentrism versus biocentrism/ecocentrism;

- $\quad$ Lack of political will in embracing complexity and uncertainty;

- Poorly developed research tools for assessing the full range of ecosystem services;

- Poorly developed decision tools for analyzing synergies and trade-offs among multiple goals;

- Lack of prioritization of monitoring and adaptive management;

- Vulnerable ecosystems that increase risk of climate change impacts.

\section{Challenges in knowledge integration}

- The dominance of the positivist/post-positivist tradition of science that emphasizes quantification, prediction, and generalization;

- The marginalization of the social sciences;

- Differences in philosophies, conceptual frameworks, and methods among disciplines;

- $\quad$ Lack of respect and trust for traditional and local knowledge;

- $\quad$ Differences in power among participants with different knowledge systems.

\section{Institutional challenges}

- $\quad$ Resistance from vested interests who are benefitting from the status quo;

- Difficulty in breaking down the path-dependent effects of the conventional paradigm;

- The difficulty of design novel institutions for landscape-scale management;

- Fragmentation of responsibilities and authority among organizations across sectors;

- Capacity constraints, e.g., funding, personnel, and time;

- $\quad$ Lack of enabling policy frameworks that support adaptive governance;

- $\quad$ Potential for unintended negative outcomes, e.g., social inequity and resource degradation.

\section{References}

1. Leopold, A. A Sand County Almanac with Essays on Conservation from Round River; Ballantine Books: New York, NY, USA, 1949.

2. Allen, P.; van Dusen, D.; Lundy, J.; Gliessman, S. Expanding the Definition of Sustainable Agriculture; Center for Agroecology and Sustainable Food Systems, UC Santa Cruz: Santa Cruz, CA, USA, 1991.

3. Ikerd, J.E. The need for a system approach to sustainable agriculture. Agric. Ecosyst. Environ. 1991, 46, 147-160. [CrossRef]

4. Horrigan, L.; Lawrence, R.S.; Walker, P. How sustainable agriculture can address the environmental and human health harms of industrial agriculture. Environ. Health Perspect. 2002, 110, 445-456. [CrossRef]

5. Fresco, L.O. Challenges for food system adaptation today and tomorrow. Environ. Sci. Policy 2009, 12, 378-385. [CrossRef]

6. Naylor, R.L. Managing Food Production Systems for Resilience. In Principles of Ecosystem Stewardship: Resilience-Based Natural Resource Management in a Changing World; Chapin, F.S., III, Kofinas, G.P., Folke, C., Eds.; Springer: New York, NY, USA, 2009; pp. 259-280. 
7. Berry, W. Another Turn of the Crank: Essays; Counterpoint Press: Berkeley, CA, USA, 2011.

8. Lu, Y.; Jenkins, A.; Ferrier, R.C.; Bailey, M.; Gordon, I.J.; Song, S.; Huang, J.; Jia, S.; Zhang, F.; Liu, X.; et al. Addressing China's grand challenge of achieving food security while ensuring environmental sustainability. Sci. Adv. 2015, 1, e1400039. [CrossRef] [PubMed]

9. FAO. Declaration on World Food Security; World Food Summit: Rome, Italy, 1996.

10. Magcale-Macandog, D.B.; Rañola, F.M.; Ranola, R.F., Jr.; Ani, P.A.B.; Vidal, N.B. Enhancing the food security of upland farming households through agroforestry in Claveria, Misamis Oriental, Philippines. Agrofor. Syst. 2010, 79, 327-342. [CrossRef]

11. Brown, M.E.; Funk, C.C. Food security under climate change. Science 2008, 139, 580-581. [CrossRef]

12. Yaro, J. Building Resilience and Reducing Vulnerability to Climate Change: Implications for Food Security in Ghana; Friedrick Ebert Stiftung: Accra, Ghana, 2013.

13. IPES. The New Science of Sustainable Food Systems: Overcoming Barriers to Food Systems Reform; International Panel of Experts on Sustainable Food Systems: Brussels, Belgium, 2015.

14. Reganold, J.P.; Papendick, R.I.; Parr, J.F. Sustainable agriculture. Sci. Am. 1990, 262, 112-120. [CrossRef]

15. Pretty, J.; Hine, R. Reducing Food Poverty with Sustainable Agriculture: A Summary of New Evidence; Centre for Environment and Society, University of Essex: Colchester, UK, 2001.

16. Stuart, D.; Gillon, S. Scaling up to address new challenges to conservation on US farmland. Land Use Policy 2013, 31, 223-236. [CrossRef]

17. Gillon, S.; Booth, E.G.; Rissman, A.R. Shifting drivers and static baselines in environmental governance: Challenges for improving and proving water quality outcomes. Reg. Environ. Chang. 2016, 16, 759-775. [CrossRef]

18. McGranahan, D.A.; Brown, P.W.; Schulte, L.A.; Tyndall, J.C. A historical primer on the US farm bill: Supply management and conservation policy. J. Soil Water Conserv. 2013, 68, 67A-73A. [CrossRef]

19. Allison, H.E.; Hobbs, R.J. Resilience, adaptive capacity, and the lock-in trap of the Western Australian agricultural region. Ecol. Soc. 2004, 9, 3. [CrossRef]

20. Thompson, J.; Scoones, I. Addressing the dynamics of agri-food systems: An emerging agenda for social science research. Environ. Sci. Policy 2009, 12, 386-397. [CrossRef]

21. Gordon, L.J.; Peterson, G.D.; Bennett, E.M. Agricultural modifications of hydrological flows create ecological surprises. Trends Ecol. Evol. 2008, 23, 211-219. [CrossRef] [PubMed]

22. Munang, R.T.; Thiaw, I.; Rivington, M. Ecosystem management: Tomorrow's approach to enhancing food security under a changing climate. Sustainability 2011, 3, 937-954. [CrossRef]

23. Lipper, L.; Thornton, P.; Campbell, B.M.; Baedeker, T.; Braimoh, A.; Bwalya, M.; Caron, P.; Cattaneo, A.; Garrity, D.; Henry, K.; et al. Climate-smart agriculture for food security. Nat. Clim. Chang. 2014, 4, 1068-1072. [CrossRef]

24. Neufeldt, H.; Jahn, M.; Campbell, B.M.; Beddington, J.R.; DeClerck, F.; De Pinto, A.; Gulledge, J.; Hellin, J.; Herrero, M.; Jarvis, A.; et al. Beyond climate-smart agriculture: Toward safe operating spaces for global food systems. Agric. Food Secur. 2013, 2, 1-6. [CrossRef]

25. Saj, S.; Torquebiau, E.; Hainzelin, E.; Pages, J.; Maraux, F. The way forward: An agroecological perspective for Cli-mate-Smart Agriculture. Agric. Ecosyst. Environ. 2017, 250, 20-24. [CrossRef]

26. Pimbert, M. Agroecology as an Alternative Vision to Conventional Development and Climate-smart Agriculture. Development 2015, 58, 286-298. [CrossRef]

27. FAO. Climate-Smart Agriculture Sourcebook: Summary; FAO: Rome, Italy, 2017.

28. Lobell, D.B.; Burke, M.B.; Tebaldi, C.; Mastrandrea, M.D.; Falcon, W.P.; Naylor, R.L. Prioritizing Climate Change Adaptation Needs for Food Security in 2030. Science 2008, 319, 607-610. [CrossRef] [PubMed]

29. Scherr, S.J.; Shames SFriedman, R. From climate-smart agriculture to climate-smart landscapes. Agric. Food Secur. 2012, 1, 12. [CrossRef]

30. IPCC. Global Warming of $1.5^{\circ}$ C: Summary for Policymakers; Intergovernmental Panel on Climate Change: Geneva, Switzerland, 2018.

31. World Bank Group. Realigning Agricultural Support to Promote Climate-Smart Agriculture; World Bank Group: Washington, DC, USA, 2018.

32. Antwi-Agyei, P.; Fraser, E.D.; Dougill, A.; Stringer, L.; Simelton, E. Mapping the vulnerability of crop production to drought in Ghana using rainfall, yield and socioeconomic data. Appl. Geogr. 2012, 32, 324-334. [CrossRef]

33. Campbell, B.M.; Thornton, P.; Zougmoré, R.; Van Asten, P.; Lipper, L. Sustainable intensification: What is its role in climate smart agriculture? Curr. Opin. Environ. Sustain. 2014, 8, 39-43. [CrossRef]

34. Partey, S.T.; Zougmoré, R.B.; Ouédraogo, M.; Campbell, B.M. Developing climate-smart agriculture to face climate varia-bility in West Africa: Challenges and lessons learnt. J. Clean. Prod. 2018, 187, 285-295. [CrossRef]

35. Pinstrup-Andersen, P. Food security: Definition and measurement. Food Secur. 2009, 1, 5-7. [CrossRef]

36. Mbow, C.; Rosenzweig, C.; Barioni, L.G.; Benton, T.G.; Herrero, M.; Krishnapillai, M.; Liwenga, E.; Pradhan, P.; Rivera-Ferre, M.; Sap-kota, T.; et al. Food security. In Climate Change and Land: An IPCC Special Report on Climate Change, Desertification, Land Degradation, Sustainable Land Management, Food Security and Greenhouse has Fluxes in Terres-Trial Ecosystems; Intergovernmental Panel on Climate Change: Geneva, Switzerland, 2019.

37. Chapin, F.S.; Carpenter, S.R.; Kofinas, G.P.; Folke, C.; Abel, N.; Clark, W.C.; Olsson, P.; Smith, D.M.S.; Walker, B.; Young, O.R.; et al. Ecosystem stewardship: Sustainability strategies for a rapidly changing planet. Trends Ecol. Evol. 2010, 25, 241-249. [CrossRef] 
38. Behnken, J.A.; Groninger, J.W.; Akamani, K. Institutional Constraints to Collaborative Ecosystem Management within a Wetlands Conservation Partnership. J. Contemp. Water Res. Educ. 2016, 158, 19-33. [CrossRef]

39. Mcleod, E.; Anthony, K.R.; Mumby, P.J.; Maynard, J.; Beeden, R.; Graham, N.; Heron, S.; Hoegh-Guldberg, O.; Jupiter, S.; MacGowan, P.; et al. The future of resilience-based management in coral reef ecosystems. J. Environ. Manag. 2019, 233, $291-301$. [CrossRef]

40. Holling, C.; Meffe, G.K. Command and Control and the Pathology of Natural Resource Management. Conserv. Biol. 1996, 10, 328-337. [CrossRef]

41. Folke, C.; Carpenter, S.; Elmqvist, T.; Gunderson, L.; Holling, C.S.; Walker, B. Resilience and sustainable development: Building adaptive capacity in a world of transformations. Ambio 2002, 31, 437-440. [CrossRef]

42. Folke, C. Resilience: The emergence of a perspective for social-ecological systems analyses. Glob. Environ. Chang. 2006, 16, 253-267. [CrossRef]

43. Bestelmeyer, B.; Briske, D.D. Grand Challenges for Resilience-Based Management of Rangelands. Rangel. Ecol. Manag. 2012, 65, 654-663. [CrossRef]

44. Ludwig, D.; Hilborn, R.; Walters, C. Uncertainty, Resource Exploitation, and Conservation: Lessons from History. Science 1993, 260, 17-36. [CrossRef] [PubMed]

45. Hughes, T.P.; Bellwood, D.R.; Folke, C.; Steneck, R.S.; Wilson, J. New paradigms for supporting the resilience of marine ecosystems. Trends Ecol. Evol. 2005, 20, 380-386. [CrossRef] [PubMed]

46. Liu, J.; Dietz, T.; Carpenter, S.R.; Alberti, M.; Folke, C.; Moran, E.; Pell, A.N.; Deadman, P.; Kratz, T.; Lubchenco, J.; et al. Complexity of coupled human and natural systems. Science 2007, 317, 1513-1516. [CrossRef] [PubMed]

47. Berkes, F. Environmental Governance for the Anthropocene? Social-Ecological Systems, Resilience, and Collaborative Learning. Sustainability 2017, 9, 1232. [CrossRef]

48. Walker, B.; Holling, C.S.; Carpenter, S.R.; Kinzig, A. Resilience, adaptability and transformability in social-ecological sys-tems. Ecol. Soc. 2004, 9, 5. [CrossRef]

49. Holling, C.S. Resilience and Stability of Ecological Systems. Annu. Rev. Ecol. Syst. 1973, 4, 1-23. [CrossRef]

50. Cortner, H.; Moote, M.A. The Politics of Ecosystem Management; Island Press: Washington, DC, USA, 1999.

51. Koontz, T.M.; Bodine, J. Implementing Ecosystem Management in Public Agencies: Lessons from the U.S. Bureau of Land Management and the Forest Service. Conserv. Biol. 2008, 22, 60-69. [CrossRef]

52. Grumbine, R.E. What Is Ecosystem Management? Conserv. Biol. 1994, 8, 27-38. [CrossRef]

53. Chapin, F.S., III; Folke, C.; Kofinas, G. A framework for understanding change. In Principles of Ecosystem Stewardship: ResilienceBased Natural Resource Management in a Changing World; Springer: New York, NY, USA, 2009; pp. 3-28.

54. Akamani, K.; Holzmueller, E.J. Socioeconomic and policy considerations in the adoption of agroforestry systems: An ecosystembased adaptive governance approach. In Agroforestry: Anectodal to Modern Science; Dagar, J.C., Tewari, V.P., Eds.; Springer: Singapore, 2017; pp. 833-855.

55. Yaffee, S.L. Ecosystem Management in Practice: The Importance of Human Institutions. Ecol. Appl. 1996, 6, 724-727. [CrossRef]

56. Berkes, F. Sustainability policy considerations for ecosystem management in central and eastern europe. Ecosyst. Health Sustain. 2016, 2, e01234. [CrossRef]

57. Carpenter, S.R.; Walker, B.; Anderies, M.J.; Abel, N. From metaphor to measurement: Resilience of what to what. Ecosystems 2011, 4, 765-781. [CrossRef]

58. Folke, C.; Chapin, F.S., III; Olsson, P. Transformations in ecosystem stewardship. In Principles of Ecosystem Stewardship: ResilienceBased Natural Resource Management in a Changing World; Springer: New York, NY, USA, 2009; pp. 103-128.

59. Akamani, K.; Holzmueller, E.J.; Groninger, J.W. Managing Wicked Environmental Problems as Complex Social-Ecological Systems: The Promise of Adaptive Governance. In Governance in Transition; Springer Science and Business Media: Berlin, Germany, 2016; pp. 741-762.

60. Folke, C.; Carpenter, S.R.; Walker, B.; Scheffer, M.; Chapin, T.; Rockström, J. Resilience thinking: Integrating resilience, adaptability and transformability. Ecol. Soc. 2010, 15, 20. [CrossRef]

61. Kofinas, G.P.; Chapin, F.S., III. Sustaining livelihoods and human well-being during social-ecological change. In Principles of Ecosystem Stewardship; Springer: New York, NY, USA, 2009; pp. 55-75.

62. Olsson, P.; Galaz, V.; Boonstra, W.J. Sustainability transformations: A resilience perspective. Ecol. Soc. 2014, 19, 1. [CrossRef]

63. DeFries, R.; Nagendra, H. Ecosystem management as a wicked problem. Science. 2017, 356, 265-270. [CrossRef]

64. Allen, C.R.; Gunderson, L.H. Pathology and failure in the design and implementation of adaptive management. J. Environ. Manag. 2011, 92, 1379-1384. [CrossRef]

65. Allen, C.R.; Fontaine, J.; Pope, K.; Garmestani, A. Adaptive management for a turbulent future. J. Environ. Manag. 2011, 92, 1339-1345. [CrossRef] [PubMed]

66. Walker, B.H.; Abel, N.; Anderies, J.M.; Ryan, P. Resilience, Adaptability and Transformability in the Goulburn-Broken Catchment, Australia. Ecol. Soc. 2009, 14, 12. [CrossRef]

67. Berardi, G.; Paci-Green, R.; Hammond, B. Stability, sustainability, and catastrophe: Applying resilience thinking to US agriculture. Hum. Ecol. Rev. 2011, 18, 115-125.

68. Brooks, N.; Grist, N.; Brown, K. Development Futures in the Context of Climate Change: Challenging the Present and Learning from the Past. Dev. Policy Rev. 2009, 27, 741-765. [CrossRef] 
69. Adger, W.N.; Brown, K.; Nelson, D.; Berkes, F.; Eakin, H.; Folke, C.; Galvin, K.A.; Gunderson, L.H.; Goulden, M.; O’Brien, K.; et al. Resilience implications of policy responses to climate change. Wiley Interdiscip. Rev. Clim. Chang. 2011, 2, 757-766. [CrossRef]

70. McLain, R.J.; Lee, R.G. Adaptive management: Promises and pitfalls. Environ. Manag. 1996, 20, 437-448. [CrossRef]

71. Akamani, K. Adaptive Water Governance: Integrating the Human Dimensions into Water Resource Governance. J. Contemp. Water Res. Educ. 2016, 158, 2-18. [CrossRef]

72. Akamani, K. Toward Ecosystem-Based Adaptation to Climate Change in West Africa: The Potential Contributions of Nongovernmental Organizations. In Adaptation to Climate Change and Variability in Rural West Africa; Yaro, J.A., Hesselberg, J., Eds.; Springer International Publishing: Cham, Switzerland, 2016; pp. 191-213.

73. Loomis, J.B. Integrated Public Lands Management: Principles and Applications to National Forests, Parks, Wildlife Refuges and BLM Lands; Columbia University Press: New York, NY, USA, 2002.

74. Thomas, J.W. Forest Service Perspective on Ecosystem Management. Ecol. Appl. 1996, 6, 703-705. [CrossRef]

75. Gilani, H.R.; Innes, J.L.; Kent, H. Developing Human Well-being Domains, Metrics and Indicators in an Ecosystem-Based Management Context in Haida Gwaii, British Columbia, Canada. Soc. Nat. Resour. 2018, 31, 1321-1337. [CrossRef]

76. Fezzi, C.; Harwood, A.R.; Lovett, A.A.; Bateman, I. The environmental impact of climate change adaptation on land use and water quality. Nat. Clim. Chang. 2015, 5, 255-260. [CrossRef]

77. Endter-Wada, J.; Blahna, D.; Krannich, R.; Brunson, M. A framework for understanding social science contributions to ecosystem management. Ecol. Appl. 1998, 8, 891-904. [CrossRef]

78. Tengö, M.; Brondizio, E.S.; Elmqvist, T.; Malmer, P.; Spierenburg, M. Connecting Diverse Knowledge Systems for Enhanced Ecosystem Governance: The Multiple Evidence Base Approach. Ambio 2014, 43, 579-591. [CrossRef]

79. Fernandino, G.; Elliff, C.I.; Silva, I.R. Ecosystem-based management of coastal zones in face of climate change impacts: Challenges and inequalities. J. Environ. Manag. 2018, 215, 32-39. [CrossRef]

80. Olsson, P.; Folke, C. Local Ecological Knowledge and Institutional Dynamics for Ecosystem Management: A Study of Lake Racken Watershed, Sweden. Ecosystems 2001, 4, 85-104. [CrossRef]

81. Folke, C.; Hahn, T.; Olsson, P.; Norberg, J. Adaptive governance of social-ecological systems. Annu. Rev. Environ. Resour. 2005, 30, 441-473. [CrossRef]

82. Reed, M.; Evely, A.C.; Cundill, G.; Fazey, I.; Glass, J.; Laing, A.; Newig, J.; Parrish, B.; Prell, C.; Raymond, C.; et al. What is Social Learning? Ecol. Soc. 2010, 15. [CrossRef]

83. Pretty, J. Participatory learning for sustainable agriculture. World Dev. 1995, 23, 1247-1263. [CrossRef]

84. Fliegel, F.; Korsching, P. Diffusion Research in Sociology; Social Ecology Free Press: Middleton, WI, USA, 2001.

85. Lélé, S.; Norgaard, R.B. Practicing Interdisciplinarity. Bioscience 2005, 55, 967-975. [CrossRef]

86. Houde, N. The Six Faces of Traditional Ecological Knowledge: Challenges and Opportunities for Canadian Co-Management Arrangements. Ecol. Soc. 2007, 12, 34. [CrossRef]

87. Folke, C.; Jansson, Å.; Rockström, J.; Olsson, P.; Carpenter, S.R.; Chapin, F.S., III; Crepin, A.-S.; Daily, G.; Danell, K. Re-connecting to the biosphere. Ambio 2011, 40, 719-738. [CrossRef] [PubMed]

88. Wondolleck, J.M.; Yaffee, S.L. Making Collaboration Work: Lessons from Innovation in Natural Resource Management; Island Press: Washington, DC, USA, 2000.

89. Olsson, P.; Folke, C.; Galaz, V.; Hahn, T.; Schultz, L. Enhancing the Fit through Adaptive Co-management: Creating and Maintaining Bridging Functions for Matching Scales in the Kristianstads Vattenrike Biosphere Reserve, Sweden. Ecol. Soc. 2007, 12, 28. [CrossRef]

90. Armitage, D.R.; Plummer, R.; Berkes, F.; Arthur, R.I.; Charles, A.T.; Davidson-Hunt, I.J.; Diduck, A.P.; Doubleday, N.C.; Johnson, D.S.; Marschke, M.; et al. Adaptive co-management for social-ecological complexity. Front. Ecol. Environ. 2009, 7, 95-102. [CrossRef]

91. Berkes, F. Evolution of co-management: Role of knowledge generation, bridging organizations and social learning. J. Environ. Manag. 2009, 90, 1692-1702. [CrossRef]

92. Akamani, K.; Hall, T.E. Determinants of the process and outcomes of household participation in collaborative forest management in Ghana: A quantitative test of a community resilience model. J. Environ. Manag. 2015, 147, 1-11. [CrossRef] [PubMed]

93. Plummer, R.; Armitage, D. A resilience-based framework for evaluating adaptive co-management: Linking ecology, economics and society in a complex world. Ecol. Econ. 2007, 61, 62-74. [CrossRef]

94. Akamani, K.; Hall, T.E. Scale and co-management outcomes: Assessing the impact of collaborative forest management on community and household resilience in Ghana. Heliyon 2019, 5, e01125. [CrossRef] [PubMed]

95. Akamani, K.; Wilson, P.I.; Hall, T.E. Barriers to collaborative forest management and implications for building the resili-ence of forest-dependent communities in the Ashanti region of Ghana. J. Environ. Manag. 2015, 151, 11-21. [CrossRef] [PubMed]

96. Olsson, P.; Gunderson, L.H.; Carpenter, S.R.; Ryan, P.; Lebel, L.; Folke, C.; Holling, C.S. Shooting the rapids: Navigating transi-tions to adaptive governance of social-ecological systems. Ecol. Soc. 2006, 11, 18. [CrossRef]

97. Walker, B.H. A Commentary on "Resilience and Water Governance: Adaptive Governance in the Columbia River Basin". Ecol. Soc. 2012, 17, 1. [CrossRef]

98. Schultz, L.; Folke, C.; Österblom, H.; Olsson, P. Adaptive governance, ecosystem management, and natural capital. Proc. Natl. Acad. Sci. USA 2015, 112, 7369-7374. [CrossRef] 
99. Chaffin, B.C.; Gosnell, H.; Cosens, B.A. A decade of adaptive governance scholarship: Synthesis and future directions. Ecol. Soc. 2014, 19, 56. [CrossRef]

100. Karpouzoglou, T.; Dewulf, A.; Clark, J. Advancing adaptive governance of social-ecological systems through theoretical multiplicity. Environ. Sci. Policy 2016, 57, 1-9. [CrossRef]

101. Dietz, T.; Ostrom, E.; Stern, P.C. The Struggle to Govern the Commons. Science 2003, 302, 1907-1912. [CrossRef]

102. Dietz, T. Bringing values and deliberation to science communication. Proc. Natl. Acad. Sci. USA 2013, 110, 14081-14087. [CrossRef]

103. Balint, P.J.; Stewart, R.E.; Desai, A. Wicked Environmental Problems: Managing Uncertainty and Conflict; Island Press: Washington, DC, USA, 2011.

104. Akamani, K.; Wilson, P.I. Toward the adaptive governance of transboundary water resources. Conserv. Lett. 2011, 4, 409-416. [CrossRef]

105. Cole, D.H. Advantages of a polycentric approach to climate change policy. Nat. Clim. Chang. 2015, 5, 114-118. [CrossRef]

106. Koontz, T.M.; Gupta, D.; Mudliar, P.; Ranjan, P. Adaptive institutions in social-ecological systems governance: A syn-thesis framework. Environ. Sci. Policy 2015, 53, 139-151. [CrossRef]

107. Makate, C. Effective scaling of climate smart agriculture innovations in African smallholder agriculture: A review of approaches, policy and institutional strategy needs. Environ. Sci. Policy 2019, 96, 37-51. [CrossRef]

108. Requena, G.; Garcia, C.; Vasquez, M. Building resilient communities in Belize through climate-smart agricultural practices. Parks Steward. Forum 2020, 36, 41-47. [CrossRef]

109. Hurlbert, M. Adaptive institutional design in agri-environmental programs. Int. J. Clim. Chang. Strat. Manag. 2014, 6, 145-165. [CrossRef]

110. Makate, C.; Makate, M.; Mango, N.; Siziba, S. Increasing resilience of smallholder farmers to climate change through multiple adoption of proven climate-smart agriculture innovations. Lessons from Southern Africa. J. Environ. Manag. 2019, 231, 858-868. [CrossRef]

111. Pagliacci, F.; Defrancesco, E.; Mozzato, D.; Bortolini, L.; Pezzuolo, A.; Pirotti, F.; Pisani, E.; Gatto, P. Drivers of farmers' adoption and continuation of climate-smart agricultural practices. A study from northeastern Italy. Sci. Total Environ. 2020, 710, 136345. [CrossRef]

112. Cortner, H.J.; Wallace, M.G.; Burke, S.; Moote, M.A. Institutions matter: The need to address the institutional challenges of ecosystem management. Landsc. Urban Plan. 1998, 40, 159-166. [CrossRef]

113. Leach, M.; Reyers, B.; Bai, X.; Brondizio, E.S.; Cook, C.; Diaz, S.; Espindola, G.; Scobie, M.; Stafford-Smith, M.; Subramanian, S.M. Equity and sustainability in the Anthropocene: A social-ecological systems perspective on their intertwined fu-tures. Glob. Sustain. 2018, 1, 1-13. [CrossRef]

114. Dewulf, A.; Karpouzoglou, T.; Warner, J.; Wesselink, A.; Mao, F.; Vos, J.; Tamas, P.; Groot, A.E.; Heijmans, A.; Ahmed, F.; et al. The power to define resilience in social-hydrological systems: Toward a power-sensitive resili-ence framework. WIREs Water 2019, 6, e1377. [CrossRef]

115. Dekker, S.C.; Kraneveld, A.D.; van Dijk, J.; Kalfagiani, A.; Knulst, A.C.; Lelieveldt, H.; Moors, E.H.M.; Muller, E.; Pieters, R.H.H.; Pie-terse, C.M.J.; et al. Towards healthy planet diets-A transdisciplinary approach to food sustainability challenges. Challenges 2020, 11, 21. [CrossRef]

116. Gillard, R.; Gouldson, A.; Paavola, J.; Van Alstine, J. Transformational responses to climate change: Beyond a systems perspective of social change in mitigation and adaptation. Wiley Interdiscip. Rev. Clim. Chang. 2016, 7, 251-265. [CrossRef]

117. Zafra-Calvo, N.; Pascual, U.; Brockington, D.; Coolsaet, B.; Vazquez, J.A.C.; Gross-Camp, N.; Palomo, I.; Burgess, N. Towards an indicator system to assess equitable management in protected areas. Biol. Conserv. 2017, 211, 134-141. [CrossRef]

118. Palmer, C. An overview of environmental ethics. In Environmental Ethics: An Anthology; Light, A., Rolston, A., III, Eds.; Blackwell Publishing: Oxford, UK, 2003; pp. 15-37.

119. Burch, S.; Gupta, A.; Inoue, C.Y.A.; Kalfagianni, A.; Persson, A.; Gerlak, A.K.; Ishii, A.; Patterson, J.; Pickering, J.; Scobie, M.; et al. New directions in earth system governance research. Earth Syst. Gov. 2019, 1, 100006. [CrossRef]

120. Akamani, K. Integrating Deep Ecology and Adaptive Governance for Sustainable Development: Implications for Protected Areas Management. Sustainability 2020, 12, 5757. [CrossRef]

121. Cain, Z.; Lovejoy, S. History and outlook for Farm Bill conservation programs. Choices 2004, 19, 37-42.

122. Graddy-Lovelace, G.; Diamond, A.; Ichikawa, N.F. Contextualizing the Farm Bill: Questions of food, land and agri-cultural governance. Renew. Agric. Food Syst. 2020, 35, 352-357. [CrossRef]

123. Lehner, P.H.; Rosenberg, N.A. A farm bill to help farmers weather climate change. J. Food Law Policy. 2018, 14, 39-55.

124. Stubbs, M. Conservation Provisions in the 2014 Farm Bill (P.L. 113-79); Congressional Research Service: Washington, DC, USA, 2014.

125. Zulauf, C. 2014 farm bill conservation (Title II) programs. Farmdoc Dly. 2014, 4, 89.

126. Reimer, A. Ecological modernization in U.S. agri-environmental programs: Trends in the 2014 Farm Bill. Land Use Policy 2015, 47, 209-217. [CrossRef]

127. Mozaffarian, D.; Griffin, T.; Mande, J. The 2018 Farm Bill-Implications and Opportunities for Public Health. JAMA 2019, 321, 835-836. [CrossRef]

128. Fischer, B.; Willis, B. Western priorities in the 2018 Farm Bill. Water Environ. Res. 2020, 18, 11-16.

129. Hipp, J.S.; Duren, C.D.; Parker, E. Building Indian country's future through food, agriculture, infrastructure, and eco-nomic development in the 2018 Farm Bill. J. Food Law Policy 2018, 14, $24-38$. 
130. Duren, C.D. The Native Farm Bill Coalition and the 2018 Farm Bill: Building a strong, sustained voice on food and agriculture issues in Indian country. Renew. Agric. Food Syst. 2020, 35, 463-464. [CrossRef]

131. Fagundes, C.; Picciano, L.; Tillman, W.; Mleczko, J.; Schwier, S.; Graddy-Lovelace, G.; Hall, F.; Watson, T. Ecological costs of discrimination: Racism, red cedar and resilience in farm bill conservation policy in Oklahoma. Renew. Agric. Food Syst. 2019, 35, 420-434. [CrossRef]

132. Gilbert, J.; Wood, S.D.; Sharp, G. Who owns the land? Agricultural land ownership by race/ethnicity. Rural Am. 2002, 17, 55-62.

133. USDA. 1997 Census of Agriculture: United States Summary and State Data; Government Printing Office: Washington, DC, USA, 1999.

134. Gilbert, J.; Sharp, G.; Felin, M.S. The loss and persistence of Black-owned farms and farmland: A review of the re-search literature and its implications. J. Rural Soc. Sci. 2002, 18, 1-30.

135. Cowan, T.; Feder, J. The Pigford Cases: USDA Settlement of Discrimination Suits by Black Farmers; Congressional Research Service: Washington, DC, USA, 2012.

136. USDA. USDA Building Blocks for Climate Smart Agriculture and Forestry: Implementation Plan and Progress Report; United States Department of Agriculture: Washington, DC, USA, 2016.

137. USDA. Climate-Smart Agriculture and Forestry Strategy: 90-Day Progress Report; United States Department of Agriculture: Washington, DC, USA, 2021.

138. Scherr, S.J.; McNeely, J.A. Biodiversity conservation and agricultural sustainability: Towards a new paradigm of 'ecoagriculture' landscapes. Philos. Trans. R. Soc. B Biol. Sci. 2007, 363, 477-494. [CrossRef]

139. Sayer, J.; Sunderland, T.; Ghazoul, J.; Pfund, J.-L.; Sheil, D.; Meijaard, E.; Venter, M.; Boedhihartono, A.K.; Day, M.; Garcia, C.; et al. Ten principles for a landscape approach to reconciling agriculture, conservation, and other competing land uses. Proc. Natl. Acad. Sci. USA 2013, 110, 8349-8356. [CrossRef]

140. Reed, J.; Van Vianen, J.; Deakin, E.L.; Barlow, B.J.; Sunderland, T. Integrated landscape approaches to managing social and environmental issues in the tropics: Learning from the past to guide the future. Glob. Chang. Biol. 2016, 22, 2540-2554. [CrossRef] [PubMed]

141. Barrios, E.; Gemmill-Herren, B.; Bicksler, A.; Siliprandi, E.; Brathwaite, R.; Moller, S.; Batello, C.; Tittonell, P. The 10 ele-ments of agroecology: Enabling transitions towards sustainable agriculture and food systems through visual narratives. Ecosyst. People 2020, 16, 230-247. [CrossRef]

142. Wezel, A.; Herren, B.G.; Kerr, R.B.; Barrios, E.; Gonçalves, A.L.R.; Sinclair, F. Agroecological principles and elements and their implications for transitioning to sustainable food systems. A review. Agron. Sustain. Dev. 2020, 40, 1-13. [CrossRef] 